\title{
Association between human leucocyte antigen subtypes and risk of end stage renal disease in Taiwanese: a retrospective study
}

\author{
Ciou-Sia Dai ${ }^{1 \dagger}$, Chen-Chung Chu ${ }^{2,3 \dagger}$, Shin-Fan Chen ${ }^{1}$, Chiao-Yin Sun ${ }^{1}$, Marie Lin ${ }^{2}$ and Chin-Chan Lee ${ }^{1,4^{*}}$
}

\begin{abstract}
Background: End stage renal disease (ESRD) is prevalent in Taiwan. Human leukocyte antigens (HLA) have been found to be associated with the pathogenesis of autoimmune diseases, allergies and inflammatory bowel diseases, and there are emerging evidences of correlations between HLA genotypes and renal diseases such as diabetic nephropathy, IgA nephropathy, and glomerulonephritis. The aim of this study is to investigate detailed HLA subtypes in a case-control study of Taiwanese individuals.

Methods: The polymorphisms of HLA class I and II antigens in ESRD patients and a healthy control group were retrospectively analyzed. The information of 141 ESRD patients was obtained from the medical record of the Keelung branch of Chang Gung Memorial Hospital and was compared to the HLA type of a control group comprized of 190 healthy unrelated Taiwanese from one of our previous studies. In order to standardize the HLA designation of prior low-resolution typings with the more advanced DNA based typings, all HLA-A, $-B$ and -DR were analyzed using a low resolution serologic equivalent.
\end{abstract}

Results: The current work suggests that HLA-DR3 (odds ratio $=1.91,95 \% \mathrm{Cl}=1.098-3.324, P=0.024, \mathrm{PC}=0.312$ ) and HLA-DR11 (odds ratio $=2.06,95 \% \mathrm{Cl}=1.133-3.761, P=0.021, P \mathrm{C}=0.273$ ) may represent susceptibility risk factors for the development of ESRD in Taiwanese individuals. On the other hand, HLA-DR8 (odds ratio $=0.47,95 \% \mathrm{Cl}=0.236-0.920$, $p=0.027 . P C=0.351)$ may be a protective factor. HLA-A and $-B$ antigens did not show any contribution of progression to ESRD. However, we note that the significance of all these findings is lost when the results are corrected for multiple comparisons according to Bonferroni. Further investigation with a larger group of patients and control is needed to resolve this issue.

Conclusions: HLA typing might be a useful clinical method for screening patients with high risk of progression to ESRD.

Keywords: ESRD, Human leukocyte antigen, Taiwan, Chronic kidney disease, HLA types

\section{Background}

The prevalence and incidence of chronic kidney disease (CKD) and end stage renal disease (ESRD) are high in Taiwan [1], and the morbidity associated with the ESRD has become a serious public health issue. One possible reason is that preventive care of CKD is low in the

\footnotetext{
* Correspondence: leefang@adm.cgmh.org.tw

${ }^{\dagger}$ Equal contributors

'Department of Internal Medicine, Division of Nephrology, Chang Gung

Memorial Hospital, Keelung, Taiwan

${ }^{4}$ Department of Nephrology, Chang Gung Memorial Hospital, Keelung, Taiwan

Full list of author information is available at the end of the article
}

Taiwan [2] and the causes of CKD among Taiwanese are diverse, the most common being diabetes mellitus, hypertension, and glomerulonephritis [3]. It is worth noting that for about $48 \%$ of early-stage and $25 \%$ of late-stage CKD patients, the causes of the disease are not well defined [3]. Although no clear risk factors have been defined for these patients it is believed that their demography and proper access to medical care largely contribute to the lack of prevention and poor management of CKD. Presently, the screening of individuals without apparent symptoms or not at risks is not applied in Taiwan [4].

\section{Biomed Central}

(c) 2015 Dai et al. Open Access This article is distributed under the terms of the Creative Commons Attribution 4.0 International License (http://creativecommons.org/licenses/by/4.0/), which permits unrestricted use, distribution, and reproduction in any medium, provided you give appropriate credit to the original author(s) and the source, provide a link to the Creative Commons license, and indicate if changes were made. The Creative Commons Public Domain Dedication waiver (http://creativecommons.org/publicdomain/zero/1.0/) applies to the data made available in this article, unless otherwise stated. 
The HLA system belongs to the major histocompatibility complex (MHC) in humans and it is located on chromosome 6p21.3. HLA genes encode cell surface molecules specialized to present antigenic peptides to Tcell receptors. MHC molecules are divided into two main classes: MHC class I and II. The heavy chain of the class I molecule is encoded by genes at the HLA-A, HLA-B, and HLA-C loci, and class II MHC molecules are encoded by genes in the HLA-DP, HLA-DQ, or HLA-DR regions [5, 6]. Specific HLA types have been known to be associated with the pathogenesis of many autoimmune diseases, allergies, and inflammatory bowel disease [7-10]. The detection of specific HLA types has proven to be a valuable tool for the diagnosis or screening of ankylosing spondylitis, inflammatory bowel disease, and multiple sclerosis [11-13]. Several emerging studies have described significant correlations between HLA and some renal diseases such as diabetic nephropathy, IgA nephropathy, and glomerulonephritis [14-16]. However, specific HLA types associated with ESRD have not been well documented. In this study, HLA class I and II polymorphisms of ESRD patients were compared to a healthy control group in an effort to provide a better understanding of the etiology of this disease.

\section{Methods}

\section{Study groups}

This retrospective analysis uses data from 141 Taiwanese ESRD patients under the age of 50 years who were awaiting kidney transplantation between the years 2002 and 2013 at the Keelung branch of Chang Gung Memorial Hospital. General clinical characteristics, HLA typing, and causes of ESRD were obtained from the health records of the organ donation and transplantation office of the hospital. The control group included 190 unrelated healthy Taiwanese individuals from a previous study that we conducted at the Mackay Memorial Hospital in Taipei to investigate the association between HLA polymorphism and multibacillary leprosy [17]. All patient and control individuals were Taiwanese, descendant of early Minnan or Hakka Chinese from the Fukien and Kwangton provinces on the south-east-coast of China who settle in Taiwan in the last 400 years. Other studies have shown that, although Minnan and Hakka speak different Chinese dialects, they have a similar HLA profile $[18,19]$. Allele frequencies of Minnan and Hakka in our previous study have been deposited in a worldwide database (http://www.allelefrequencies.net/). In this retrospective study, ethical approval was obtained by the institutional review board of medical ethics and the human body test committee at the Chang Gung Memorial Hospital (102-5322B).

\section{HLA typing}

HLA typing was initially performed by serological method or DNA based typing method at the time of the onset of the disease. The 74 ESRD patients who entered the transplantation waiting list before year 2008 were typed by complement dependent cytotoxicity $(\mathrm{CDC})$ testing method,whereas the 67 ESRD patients who enrolled after the year 2008 were typed by reverse line blot using the RELI $^{\text {su }}$ SSO typing kit (Dynal Biotech, Bromborough, Wirral, UK). Finally, DNA-based typing results were converted to serologic designations according to the HLA dictionary 2008 [20].

\section{Statistical analysis}

Antigen counts were obtained from the serologic data. Statistical analyses for the association between patient and control groups were performed by estimating the odds ratios (OR) and $95 \%$ confidence intervals (95\% CI) using the approximation method of Woolf using GraphPadInStat version 3.0 (GraphPad Software, San Diego, CA). Two tailed $P$ values were estimated by Fisher's exact test. A $P$ value less or equal to 0.05 was considered to be significant. Corrected $P$ values $(P \mathrm{c})$ were also calculated by multiplying the $P$ values by the number of antigens represented in the samples (according to the Bonferroni's correction).

\section{Results}

\section{General characteristics of the study population}

HLA polymorphism was analyzed to determine the differences between 190 healthy control individuals and 141 ESRD patients (Table 1). Most ESRD patients had unknown primary disease $(n=89,63.2 \%)$, and diabetes mellitus type 2 was the most common cause of ESRD $(n=30,21.3 \%)$.

Table 1 Baseline characteristics of the study population

\begin{tabular}{ll}
\hline Total & 141 \\
Male/Female & $80(56.7 \%) / 61$ (43.3\%) \\
$\begin{array}{l}\text { Mean age at the time of end stage renal } \\
\text { disease }\end{array}$ & $40 \pm 12$ y \\
Causes of end stage renal disease & \\
1. Diabetes mellitus & $30(21.3 \%)$ \\
2. IgA nephropathy & $9(6.4 \%)$ \\
3. Autosomal polycystic kidney disease & $4(2.8 \%)$ \\
4. Focal segmental glomerulosclerosis & $3(2.1 \%)$ \\
5. Minimal change disease & $3(2.1 \%)$ \\
6. Rapidly progressive GN & $1(0.7 \%)$ \\
7. Membranous nephropathy & $1(0.7 \%)$ \\
8. Mesangioproliferative GN & $1(0.7 \%)$ \\
9. Unknown & $89(63.2 \%)$
\end{tabular}


Association of HLA-A and HLA-B antigens with ESRD

HLA class I analysis in patients and control (Table 2 and Table 3) revealed 13 HLA-A and 28 HLA-B antigens. The most common HLA-A locus antigens with antigen frequency greater than $10 \%$ in the two groups were A11, A2, A24, and A33. Similarly, the most common HLA-B locus antigens were B60, B46, and B58. We note that HLA-A and -B antigens distribution in the two groups were similar and that no significant differences (odds ratio) were found between them.

\section{Association of HLA-DR antigens with ESRD}

The combined HLA class II polymorphism revealed 13 DR antigens (Table 4) with HLA-DR9, DR4, DR11, DR12, DR15, DR8, DR3, DR14, and DR16 being the only antigens having a frequency greater than $10 \%$. ESRD disease assessment revealed positive associations with HLA-DR3 (odds ratio $=1.91,95 \% \mathrm{CI}=1.098-3.324, P=$ 0.024, $P_{\mathrm{C}}=0.312$ ) and HLA-DR11 (odds ratio $=2.06$, $95 \% \mathrm{CI}=1.133-3.761, \quad P=0.021, \quad P \mathrm{C}=0.273)$, and a negative association with HLA-DR8 (odds ratio $=0.47$, $95 \% \mathrm{CI}=0.236-0.920, P=0.027, \mathrm{Pc}=0.351) \quad($ Table 4$)$. We note that the significance of these associations is lost after establishing Bonferroni correction.

Most ESRD patients had unknown etiology $(N=89$, $63.2 \%)$ and only $21.3 \%(N=30)$ were Type II diabetes mellitus patients. After exclusion of all DM patients (Table 5), HLA-DR3 (OR $=1.95, P=0.031, P \mathrm{C}=0.403$ ) and DR11 (OR $=2.11, P=0.030, P \mathrm{C}=0.39)$ remained significantly associated to ESRD whereas HLA-DR8 showed protection to the disease $(\mathrm{OR}=0.40, P=0.026$, $P \mathrm{C}=0.338$ ). In Brief associations of DR antigens with non-DM patients remained unchanged and further suggest that the association of DR3 and DR11 is not relevant to the presence or absence of DM.

\section{Discussion}

ESRD is a condition where patients are imperatively dependent on renal replacement in order to avoid lifethreatening uremia [21]. The HLA system has been found to be associated with the pathogenesis of autoimmune diseases, inflammatory bowel disease, allergies and some renal diseases such as diabetic nephropathy, IgA nephropathy and glomerulonephritis. Identification and analysis of the HLA polymorphism in ESRD patients is not only important for the determination of a possible association of the disease with HLA, but is also an absolute requirement for the selection of an optimal kidney matching for transplantation in these patients [22].

In this study, HLA-DR3, and HLA-DR11 antigen frequencies in the ESRD patient group were significantly higher than in the control group (DR3: cases 24.8 vs control $14.7 \%$; DR11: case 21.3 vs control $11.6 \%)$ with OR values of $1.91(P=0.024)$ and $2.06(P=0.021)$, respectively. On the other hand, HLA-DR8 was significantly lower in the ESRD patient group than in the control group (case 9.2 vs control $17.9 \%$; OR 0.47; $P=$ 0.027). However, after Bonferroni' correction, all corrected $P$ values were greater than 0.05 (Pc $>0.05)$. Although the uncorrected $P$ value may suggest type I error, we can estimate that a data set only three times larger would maintain significance after Bonferroni correction. Such reachable prospect justifies further analyses for confirmation of these results.

Table 2 HLA-A antigen frequency among individuals with ESRD and healthy controls

\begin{tabular}{|c|c|c|c|c|c|c|c|}
\hline \multirow[b]{2}{*}{ Antigens } & \multicolumn{2}{|c|}{ Patients $N=141$} & \multicolumn{2}{|c|}{ Control $N=190$} & \multirow[b]{2}{*}{ Odds ratio } & \multirow[b]{2}{*}{$95 \%$ confidence interval $(95 \%$ Cl) } & \multirow[b]{2}{*}{$P$ value } \\
\hline & Count & Antigen frequency & Count & Antigen frequency & & & \\
\hline$\overline{\mathrm{A} 1}$ & 4 & $2.8 \%$ & 1 & $0.5 \%$ & 5.52 & $0.610-49.920$ & NS \\
\hline $\mathrm{A} 2$ & 61 & $43.3 \%$ & 96 & $50.5 \%$ & 0.75 & $0.482-1.157$ & NS \\
\hline A3 & 2 & $1.4 \%$ & & & 6.83 & $0.325-143.350$ & NS \\
\hline A24 & 48 & $34.0 \%$ & 59 & $31.1 \%$ & 1.15 & $0.720-1.824$ & NS \\
\hline A11 & 86 & $61.0 \%$ & 112 & $58.9 \%$ & 1.09 & $0.698-1.699$ & NS \\
\hline A26 & 5 & $3.5 \%$ & 10 & $5.3 \%$ & 0.66 & $0.221-1.981$ & NS \\
\hline A29 & 1 & $0.0 \%$ & 1 & $0.5 \%$ & 1.35 & $0.084-21.771$ & NS \\
\hline A30 & 7 & $5.0 \%$ & 3 & $1.6 \%$ & 3.26 & $0.827-12.822$ & NS \\
\hline A31 & 3 & $2.1 \%$ & 9 & $4.7 \%$ & 0.44 & $0.116-1.645$ & NS \\
\hline A32 & & & 2 & $1.1 \%$ & 0.27 & $0.013-5.593$ & NS \\
\hline A33 & 32 & $22.7 \%$ & 37 & $19.5 \%$ & 1.21 & $0.712-2.069$ & NS \\
\hline A34 & 3 & $2.1 \%$ & & & 9.63 & $0.493-187.918$ & NS \\
\hline A68 & & & 1 & $0.5 \%$ & 0.45 & $0.018-11.040$ & NS \\
\hline
\end{tabular}


Table 3 HLA-B antigen frequency among individuals with ESRD and healthy controls

\begin{tabular}{|c|c|c|c|c|c|c|c|}
\hline \multirow[b]{2}{*}{ Antigens } & \multicolumn{2}{|c|}{ Patients $N=141$} & \multicolumn{2}{|c|}{ Control $N=190$} & \multirow[b]{2}{*}{ Odds ratio } & \multirow[b]{2}{*}{$95 \%$ confidence interval (95\%Cl) } & \multirow[b]{2}{*}{$P$ value } \\
\hline & Count & Antigen frequency & Count & Antigen frequency & & & \\
\hline B13 & 25 & $17.7 \%$ & 34 & $17.9 \%$ & 0.99 & $0.560-1.748$ & NS \\
\hline B18 & 1 & $0.7 \%$ & 1 & $0.5 \%$ & 1.35 & $0.083-21.771$ & NS \\
\hline B27 & 12 & $8.5 \%$ & 15 & $7.9 \%$ & 1.09 & $0.491-2.397$ & NS \\
\hline B35 & 10 & $7.1 \%$ & 10 & $5.3 \%$ & 1.37 & $0.556-3.397$ & NS \\
\hline B37 & 2 & $1.4 \%$ & 1 & $0.5 \%$ & 2.72 & $0.244-30.292$ & NS \\
\hline B38 & 11 & $7.8 \%$ & 16 & $8.4 \%$ & 0.92 & $0.413-2.049$ & NS \\
\hline B39 & 10 & $7.1 \%$ & 8 & $4.2 \%$ & 1.74 & $0.667-4.520$ & NS \\
\hline B44 & 1 & $0.7 \%$ & 2 & $1.1 \%$ & 0.67 & $0.060-7.479$ & NS \\
\hline B46 & 28 & $19.9 \%$ & 46 & $24.2 \%$ & 0.78 & $0.456-1.318$ & NS \\
\hline B48 & 7 & $5.0 \%$ & 5 & $2.6 \%$ & 1.93 & $0.601-6.221$ & NS \\
\hline B51 & 10 & $7.1 \%$ & 21 & $11.1 \%$ & 0.61 & $0.278-1.349$ & NS \\
\hline B52 & 2 & $1.4 \%$ & 2 & $1.1 \%$ & 1.35 & $0.188-9.720$ & NS \\
\hline B54 & 10 & $7.1 \%$ & 15 & $7.9 \%$ & 0.89 & $0.388-2.046$ & NS \\
\hline B55 & 8 & $5.7 \%$ & 13 & $6.8 \%$ & 0.82 & $0.330-2.033$ & NS \\
\hline B56 & 5 & $3.5 \%$ & 3 & $1.6 \%$ & 2.29 & $0.539-9.753$ & NS \\
\hline B58 & 34 & $24.1 \%$ & 37 & $19.5 \%$ & 1.31 & $0.776-2.226$ & NS \\
\hline B60 & 46 & $32.6 \%$ & 66 & $34.7 \%$ & 0.91 & $0.573-1.444$ & NS \\
\hline B61 & 16 & $11.3 \%$ & 16 & $8.4 \%$ & 1.39 & $0.671-2.889$ & NS \\
\hline B62 & 13 & $9.2 \%$ & 18 & $9.5 \%$ & 0.97 & $0.459-2.053$ & NS \\
\hline B67 & & & 1 & $0.5 \%$ & 0.45 & $0.018-11.040$ & NS \\
\hline B7 & & & 2 & $1.1 \%$ & 0.27 & $0.013-5.593$ & NS \\
\hline B71 & & & 2 & $1.1 \%$ & 0.27 & $0.013-5.593$ & NS \\
\hline B75 & 17 & $12.1 \%$ & 21 & $11.1 \%$ & 1.10 & $0.556-2.178$ & NS \\
\hline B76 & 2 & $1.4 \%$ & 1 & $0.5 \%$ & 2.72 & $0.244-30.292$ & NS \\
\hline B70 & 1 & $0.7 \%$ & 0 & & 4.07 & $0.165-100.598$ & NS \\
\hline B57 & 1 & $0.7 \%$ & 0 & & 4.07 & $0.165-100.598$ & NS \\
\hline B81 & 1 & $0.7 \%$ & 0 & & 4.07 & $0.165-100.598$ & NS \\
\hline B40 & 1 & $0.7 \%$ & 0 & & 4.07 & $0.165-100.598$ & NS \\
\hline
\end{tabular}

$N$ number, NS not significant

\section{HLA-DR3}

Previously reported associations between HLA class I and II, and ESRD among patients with history of diabetes, hypertension, and various types of glomerulonephritis are summarized in Table 6 [16, 23-33]. These studies show that HLA-DR3 was significantly associated with membranous nephropathy in Chinese, French, British, Chilean, and North American [50,51,52], DR3 was also associated with the occurrence of diabetic nephropathy $[24,29,30,34,35]$, and was protective against the occurrence of idiopathic IgA nephropathy [36]. In support to these studies, our results show that HLA-DR3 was increased in the ESRD group (patients 23 vs control 14\%) with an OR significant before Bonferroni correction.
We further note that HLA-DR11 (Table 6) was associated with diabetic nephropathy in Egyptian population [35] and other diseases such as celiac disease, rheumatic heart disease, and cancer [37-40]. In our study, the occurrence of HLA-DR11 was significantly higher in the ESRD group. Similarly to HLA-DR3, the significance of HLA-DR11 was lost after Bonferroni correction. Again, while suggesting that a larger data set is required to support to these results, one should be aware that DR3 and DR11 are potentially valuable predictors for evaluating the risk of ESRD in the Taiwanese population.

HLA-DR8 has been associated with the prevalence of DESRD in individuals under 50 years [15]. In our study, the presence of HLA-DR8 was significantly lower in 
Table 4 HLA-DR antigen frequency among individuals with ESRD and healthy controls

\begin{tabular}{|c|c|c|c|c|c|c|c|c|}
\hline \multirow[b]{2}{*}{ Antigens } & \multicolumn{2}{|c|}{ Patients $N=141$} & \multicolumn{2}{|c|}{ Control $N=190$} & \multirow[b]{2}{*}{ Odds ratio } & \multirow[b]{2}{*}{$95 \%$ confidence interval $(95 \%$ Cl) } & \multirow[b]{2}{*}{$P$ value } & \multirow[b]{2}{*}{ Corrected $P$ value } \\
\hline & Count & Antigen frequency & Count & Antigen frequency & & & & \\
\hline$\overline{D R 1}$ & & & 3 & $1.6 \%$ & 0.19 & $0.010-3.695$ & NS & \\
\hline DR3 & 35 & $24.8 \%$ & 28 & $14.7 \%$ & 1.91 & $1.098-3.324$ & 0.024 & 0.312 \\
\hline DR4 & 48 & $34.0 \%$ & 54 & $28.4 \%$ & 1.30 & $0.813-2.079$ & NS & \\
\hline DR7 & 9 & $6.4 \%$ & 4 & $2.1 \%$ & 3.17 & $0.956-10.513$ & NS & \\
\hline DR8 & 13 & $9.2 \%$ & 34 & $17.9 \%$ & 0.47 & $0.236-0.920$ & 0.027 & 0.351 \\
\hline DR9 & 44 & $31.2 \%$ & 56 & $29.5 \%$ & 1.09 & $0.676-1.743$ & NS & \\
\hline DR10 & 6 & $4.3 \%$ & 4 & $2.1 \%$ & 2.07 & $0.572-7.466$ & NS & \\
\hline DR11 & 30 & $21.3 \%$ & 22 & $11.6 \%$ & 2.06 & $1.133-3.761$ & 0.021 & 0.273 \\
\hline DR12 & 29 & $20.6 \%$ & 48 & $25.3 \%$ & 0.77 & $0.454-1.292$ & NS & \\
\hline DR13 & 6 & $4.3 \%$ & 17 & $8.9 \%$ & 0.45 & $0.174-1.178$ & NS & \\
\hline DR14 & 14 & $9.9 \%$ & 25 & $13.2 \%$ & 0.73 & $0.364-1.456$ & NS & \\
\hline DR15 & 24 & $17.0 \%$ & 36 & $18.9 \%$ & 0.88 & $0.496-1.551$ & NS & \\
\hline DR16 & 10 & $7.1 \%$ & 25 & $13.2 \%$ & 0.50 & $0.23-1.086$ & NS & \\
\hline
\end{tabular}

$N$ number, NS not significant

patients than in the control group and may have a protective influence against the incidence of ESRD.

\section{HLA-DR4}

In previous studies, HLA-DR4 has been associated with immune complex-mediated rapidly progressive glomerulonephritis in populations from China, Italy and the USA [23, 28, 32, 33] and showed strong association with the occurrence of IgA nephropathy in the Japanese and with idiopathic focal sclerosing glomerulosclerosis in the Brazillian population [25, 41]. Individuals with HLA-DR4 were also susceptible to DESRD in patients under 50 years old from Canada [15], but was protective from diabetic nephropathy in the US and Mexican populations [29, 34]. In this study, the frequency of HLA-DR4 is higher in patients (34\%) than it in the control group (28\%), but this difference was not significant.

In brief, this study reports two HLA antigens (DR3 and DR11) that showed significant associations with the risk of progression to ESRD. However, both control and disease study groups were too small to sustain the significance after Bonferonni correction. However, although our data set was small, we find that after stratification of our data set for non-T2DM the same level of significance was obtained suggesting that DR3 and DR11 association to ESRD may be independent to any specific disease group.

Table 5 HLA-DR antigen frequency in healthy control and non-DM individuals with ESRD

\begin{tabular}{|c|c|c|c|c|c|c|c|c|}
\hline \multirow[b]{2}{*}{ Antigens } & \multicolumn{2}{|c|}{ Patients $(N=111)$} & \multicolumn{2}{|c|}{ Control $(N=190)$} & \multirow[b]{2}{*}{ Odd ratios } & \multirow[b]{2}{*}{95 \% confidence interval (95 \% Cl) } & \multirow[b]{2}{*}{$P$ value } & \multirow[b]{2}{*}{ Pc value } \\
\hline & Count & Antigen frequency & Count & Antigen frequency & & & & \\
\hline DR1 & & & 3 & $1.60 \%$ & 0.24 & $0.012-4.694$ & NS & \\
\hline DR3 & 28 & $25.20 \%$ & 28 & $14.70 \%$ & 1.95 & $1.085-3.510$ & 0.031 & 0.403 \\
\hline DR4 & 36 & $32.40 \%$ & 54 & $28.40 \%$ & 1.21 & $0.728-2.008$ & NS & \\
\hline DR7 & 8 & $7.20 \%$ & 4 & $2.10 \%$ & 3.61 & $1.062-12.284$ & 0.036 & 0.468 \\
\hline DR8 & 9 & $8.10 \%$ & 34 & $17.90 \%$ & 0.4 & $0.186-0.880$ & 0.026 & 0.338 \\
\hline DR9 & 35 & $31.50 \%$ & 56 & $29.50 \%$ & 1.1 & $0.663-1.831$ & NS & \\
\hline DR10 & 5 & $4.50 \%$ & 4 & $2.10 \%$ & 2.19 & $0.577-8.346$ & NS & \\
\hline DR11 & 24 & $21.60 \%$ & 22 & $11.60 \%$ & 2.11 & $1.118-3.970$ & 0.03 & 0.39 \\
\hline DR12 & 26 & $23.40 \%$ & 48 & $25.30 \%$ & 0.9 & $0.523-1.565$ & NS & \\
\hline DR13 & 5 & $4.50 \%$ & 17 & $8.90 \%$ & 0.48 & $0.172-1.340$ & NS & \\
\hline DR14 & 11 & $9.90 \%$ & 25 & $13.20 \%$ & 0.73 & $0.3425-1.539$ & NS & \\
\hline DR15 & 17 & $15.30 \%$ & 36 & $18.90 \%$ & 0.77 & $0.412-1.454$ & NS & \\
\hline DR16 & 8 & $7.20 \%$ & 25 & $13.20 \%$ & 0.51 & $0.223-1.179$ & NS & \\
\hline
\end{tabular}


Table 6 Review of systemic and kidney diseases associated with HLA type

\begin{tabular}{|c|c|c|c|c|c|c|}
\hline \multirow[t]{2}{*}{ Population } & \multirow[t]{2}{*}{ Study End point } & \multicolumn{2}{|l|}{ Susceptibility } & \multicolumn{2}{|l|}{ Protection } & \multirow[t]{2}{*}{ Reference } \\
\hline & & MHC class I & MHC class II & MHC class I & MHC class II & \\
\hline Taiwan & ESRD & & DR3,DR11 & & DR8 & $*$ \\
\hline Kuwaiti & ESRD & B8 & & A28 & DR11 & {$[42]$} \\
\hline \multirow[t]{2}{*}{ Saudi } & ESRD & & DQB1*03(8) & Cw2 & & [43] \\
\hline & Glomerulonephritis & & & & & \\
\hline China & $\begin{array}{l}\text { Poor renal outcome of } \\
\text { ANCA related vasculitis }\end{array}$ & & $\begin{array}{l}\text { DRB1*04:05, } \\
\text { DPB1*0402 }\end{array}$ & & & [33] \\
\hline China & $\begin{array}{l}\text { Cresentic GN in anti-GBM } \\
\text { disease }\end{array}$ & & $\begin{array}{l}\text { DRB1*1501 } \\
\text { DRB1*0404 }\end{array}$ & & & {$[32]$} \\
\hline Italy & $\begin{array}{l}\text { Churg-Strauss syndrome } \\
\text { with renal involvement }\end{array}$ & & $\mathrm{DRB}^{*} 04$ & & & [28] \\
\hline United States & Anti-GBM disease & & $\begin{array}{l}\text { DRB1*15 } \\
\text { DRB1*04 }\end{array}$ & & $\mathrm{DRB} 1 * 07$ & [23] \\
\hline Taiwan & Lupus nephritis & & & & DRB $1 * 1202$ & [31] \\
\hline Italy & Lupus nephritis & & $\begin{array}{l}\text { DRB1*1501, } \\
\text { DQA } 1 * 0101\end{array}$ & & DQA1*0102 & {$[26]$} \\
\hline United States & IgA nephropathy & B27 & DR1 & & DR2 & {$[44]$} \\
\hline Japan & IgA nephropathy & & DR4 & & & [14] \\
\hline France & IgA nephropathy & B35 & & & & [45] \\
\hline Europe & IgA nephropathy & Bw35 & & & & {$[46]$} \\
\hline Netherland & $\begin{array}{l}\text { Idiopathic IgA } \\
\text { nephropathy }\end{array}$ & B35 & DR5 & $\mathrm{B} 7, \mathrm{~B} 8$ & DR2,DR3 & [36] \\
\hline China & IgA nephropathy & & DR14, DR3 & & DR7 & [47] \\
\hline Sweden & IgA nephropathy & & DR4 & & & [16] \\
\hline France & IgA nephropathy & & DQB1*0301 & & & [48] \\
\hline Japan & IgA nephropathy & Bw35 & DR4 & & & [41] \\
\hline Japan & IgA nephropathy & & DQw4 & & & [49] \\
\hline France & Membranous GN & & DR3 & & & {$[50]$} \\
\hline Taiwan & Membranous GN & & DR3 & & & [51] \\
\hline UnitedStates & Membranous GN & & DR3, DR5 & & DR7 & {$[52]$} \\
\hline Netherland & Idiopathic MN & B8 & DR3 & & & [53] \\
\hline South Africa & $\begin{array}{l}\text { HBV- associated } \\
\text { membranous } \\
\text { GN in children }\end{array}$ & & $\mathrm{DQB1} 1{ }^{* 0603}$ & & & [54] \\
\hline Korea & HBV associated GN & & $\begin{array}{l}\text { DR2, DRB1*15:01, } \\
\text { DRB1*15:02 }\end{array}$ & & $\begin{array}{l}\text { DRB1*1302, } \\
\text { DQB1*0402, } \\
\text { DQB1*0604 }\end{array}$ & [27] \\
\hline United States & $\begin{array}{l}\text { Heroin- associated } \\
\text { nephropathy }\end{array}$ & Bw53 & & & & {$[55]$} \\
\hline United States & Hypertensive renal failure & B35 & DR3 & $\mathrm{A} 1, \mathrm{~B} 8$ & & {$[56]$} \\
\hline \multirow[t]{2}{*}{ Brazil } & Idiopathic FSGS & & DR4 & & & {$[25]$} \\
\hline & Systemic diseases & & & & & \\
\hline Mexico & $\begin{array}{l}\text { Type } 2 \text { diabetes mellitus } \\
\text { with ESRD }\end{array}$ & & $\begin{array}{l}\text { DRB1*1502 } \\
\text { DQB1*0501 }\end{array}$ & & $\mathrm{DRB} 1 * 0407$ & {$[34]$} \\
\hline London & Early diabetic nephropathy & $\mathrm{A} 2$ & & & & [24] \\
\hline Turkey & $\begin{array}{l}\text { Amyloidosis and diabetic } \\
\text { nephropathy }\end{array}$ & B58 & $\mathrm{DR}^{*} 03$ & & & [30] \\
\hline
\end{tabular}


Table 6 Review of systemic and kidney diseases associated with HLA type (Continued)

\begin{tabular}{lllll}
\hline United States & Diabetic nephropathy & & & DRB1*04 \\
Canada & Diabetes related ESRD in $\leq 50 y$ & A2 & DR4, DR8 & [29] \\
Egypt & Diabetic nephropathy & A2, B8 & DRB1*3, DRB1*11 & [15] \\
\hline
\end{tabular}

DESRD diabetic related end stage renal disease

$y$ years

* Results of this study

To the best of our knowledge, this analysis is the first case-control study to analyze the association between the HLA polymorphisms and the risk to develop ESRD in a Taiwanese population. Further, the analysis showed several significant DR associations with ESRD indicating that HLA class II polymorphism might be a useful clinical tool for screening patients with high risk of ESRD and constitute sufficient motivating elements to undertake early preventive measures in the management of ESRD.

\section{Conclusion}

HLA polymorphism might be a useful clinical tool for screening patients with high risk of ESRD. This analysis used small population case and control data set and warrant further study to confirm these results.

\section{Abbreviations}

ESRD: End stage renal disease; HLA: Human leukocyte antigen.

\section{Competing interests}

The authors declare no financial conflicts or other conflicts of interest.

\section{Authors' contributions}

CSD, SFC, CYS and CCL are responsible for patient care, patient data collection and drafting the manuscript. CCC and ML provided the control group data. CSD and CCC participated in the design of the study, performed the statistical analysis and revised the manuscript. CCL and ML conceived of the study, and participated in its design and coordination. They all reviewed and approved the manuscript.

\section{Acknowledgements}

The authors wish to express their deepest gratitude to all the patients who participated in this study.

\section{Author details}

${ }^{1}$ Department of Internal Medicine, Division of Nephrology, Chang Gung Memorial Hospital, Keelung, Taiwan. ${ }^{2}$ Department of Medical Research, Mackay Memorial Hospital, Taipei, Taiwan. ${ }^{3}$ Department of Bioscience Technology, Chung Yuan Christian University, Chung-Li, Taiwan. ${ }^{4}$ Department of Nephrology, Chang Gung Memorial Hospital, Keelung, Taiwan.

Received: 8 January 2015 Accepted: 14 October 2015

Published online: 30 October 2015

\section{References}

1. Kuo HW, Tsai SS, Tiao MM, Yang CY. Epidemiological features of CKD in Taiwan. Am J Kidney Dis : Off J National Kidney Foundation. 2007:49(1):46-55.

2. Hwang SJ, Tsai JC, Chen HC. Epidemiology, impact and preventive care of chronic kidney disease in Taiwan. Nephrology. 2010;15 Suppl 2:3-9.

3. Wu IW, Hsu KH, Lee CC, Sun CY, Hsu HJ, Hung MJ, et al. Re-evaluating the predictive roles of metabolic complications and clinical outcome according to eGFR levels - a four-years prospective cohort study in Taiwan. BMC Nephrol. 2013;14.

4. Qaseem A, Hopkins Jr RH, Sweet DE, Starkey M, Shekelle P, Clinical Guidelines Committee of the American College of P. Screening, monitoring, and treatment of stage 1 to 3 chronic kidney disease: A clinical practice guideline from the American College of Physicians. Ann Intern Med. 2013;159(12):835-47.

5. Parham P, Ohta T. Population biology of antigen presentation by MHC class I molecules. Science. 1996;272(5258):67-74.

6. Marsh SG, System WHONCfFotH. Nomenclature for factors of the HLA system, update April 2010. Tissue Antigens. 2010;76(6):501-8.

7. Lange CF. HL-A histocompatibility antigens and their relation to disease. Prog Clin Pathol. 1975;6:137-62.

8. Tsao BP. An update on genetic studies of systemic lupus erythematosus. Curr Rheumatol Rep. 2002;4(4):359-67.

9. Phillips EJ, Mallal SA. HLA and drug-induced toxicity. Curr Opin Mol Ther 2009;11(3):231-42.

10. Megiorni F, Pizzuti A. HLA-DQA1 and HLA-DQB1 in Celiac disease predisposition: practical implications of the HLA molecular typing. J Biomed Sci. 2012;19:88.

11. van der Gaag R, Luyendijk L, Linssen A, Kijlstra A. Expression of HLA-B27 antigens on mononuclear leucocytes in ankylosing spondylitis. Clin Exp Immunol. 1985;60(2):311-5.

12. Ahmad T, Marshall SE, Jewell D. Genetics of inflammatory bowel disease: the role of the HLA complex. WJG. 2006;12(23):3628-35.

13. Kallaur AP, Kaimen-Maciel DR, Morimoto HK, Watanabe MA, Georgeto SM, Reiche EM. Genetic polymorphisms associated with the development and clinical course of multiple sclerosis (review). Int J Mol Med. 2011;28(4):467-79.

14. Kohara M, Naito S, Arakawa K, Miyata J, Chihara J, Taguchi T, et al. The strong association of HLA-DR4 with spherical mesangial dense deposits in IgA nephropathy. J Clin Lab Immunol. 1985;18(4):157-60.

15. Dyck R, Bohm C, Klomp H. Increased frequency of HLA A2/DR4 and A2/DR8 haplotypes in young saskatchewan aboriginal people with diabetic endstage renal disease. Am J Nephrol. 2003;23(3):178-85.

16. Vuong MT, Lundberg S, Gunnarsson I, Wramner L, Lundstrom E, Fernstrom $A$, et al. Genetic evidence for involvement of adaptive immunity in the development of IgA nephropathy: MHC class II alleles are protective in a Caucasian population. Hum Immunol. 2013;74(8):957-60.

17. Hsieh NK, Chu CC, Lee NS, Lee HL, Lin M. Association of HLA-DRB1*0405 with resistance to multibacillary leprosy in Taiwanese. Hum Immunol. 2010;71(7):712-6.

18. Shaw CK, Chen LL, Lee A, Lee TD. Distribution of HLA gene and haplotype frequencies in Taiwan: a comparative study among Min-nan, Hakka, Aborigines and Mainland Chinese. Tissue Antigens. 1999;53(1):51-64.

19. Lin M, Chu CC, Chang SL, Lee HL, Loo JH, Akaza T, et al. The origin of Minnan and Hakka, the so-called "Taiwanese", inferred by HLA study. Tissue Antigens. 2001;57(3):192-9.

20. Holdsworth R, Hurley CK, Marsh SG, Lau M, Noreen HJ, Kempenich JH, et al. The HLA dictionary 2008: a summary of HLA-A, $-B,-C,-D R B 1 / 3 / 4 / 5$, and $-D Q B 1$ alleles and their association with serologically defined HLA-A, $-B,-C,-D R$, and -DQ antigens. Tissue Antigens. 2009;73(2):95-170.

21. van Dijk PC, Jager KJ, de Charro F, Collart F, Cornet R, Dekker FW, et al. Renal replacement therapy in Europe: the results of a collaborative effort by the ERA-EDTA registry and six national or regional registries. Nephrol Dial Transplant: Off Pub Euro Dialysis Transplant Assoc - European Renal Assoc. 2001;16(6):1120-9.

22. Cao Q, Xie D, Liu J, Zou H, Zhang Y, Zhang H, et al. HLA polymorphism and susceptibility to end-stage renal disease in Cantonese patients awaiting kidney transplantation. PLoS One. 2014;9(6), e90869.

23. Rees AJ, Peters DK, Amos N, Welsh Kl, Batchelor JR. The influence of HLAlinked genes on the severity of anti-GBM antibody-mediated nephritis. Kidney Int. 1984:26(4):445-50.

24. Watts GF, Taub N, Gant V, Wilson I, Shaw KM. The immunogenetics of early nephropathy in insulin-dependent diabetes mellitus: association between the HLA-A2 antigen and albuminuria. Q J Med. 1992;83(302):461-71. 
25. Gerbase-Delima M, Pereira-Santos A, Sesso R, Temin J, Aragao ES, Ajzen H, et al. Idiopathic focal segmental glomerulosclerosis and HLA antigens. Braz J Med Biol Res. 1998;31(3):387-9.

26. Marchini M, Antonioli R, Lleo A, Barili M, Caronni M, Origgi L, et al. HLA class II antigens associated with lupus nephritis in Italian SLE patients. Hum Immunol. 2003;64(4):462-8.

27. Park MH, Song EY, Ahn C, Oh KH, Yang J, Kang SJ, et al. Two subtypes of hepatitis B virus-associated glomerulonephritis are associated with different HLA-DR2 alleles in Koreans. Tissue Antigens. 2003;62(6):505-11.

28. Vaglio A, Martorana D, Maggiore U, Grasselli C, Zanetti A, Pesci A, et al. HLADRB4 as a genetic risk factor for Churg-Strauss syndrome. Arthritis Rheum. 2007;56(9):3159-66.

29. Cordovado SK, Zhao Y, Warram JH, Gong H, Anderson KL, Hendrix MM, et al. Nephropathy in type 1 diabetes is diminished in carriers of HLA-DRB $1{ }^{*} 04$ : the genetics of kidneys in diabetes (GoKinD) study. Diabetes. 2008;57(2):518-22.

30. Karahan GE, Seyhun Y, Oguz FS, Kekik C, Onal AE, Yazici H, et al. Impact of $\mathrm{HLA}$ on the underlying primary diseases in Turkish patients with end-stage renal disease. Ren Fail. 2009;31(1):44-9.

31. Pan CF, Wu CJ, Chen HH, Dang CW, Chang FM, Liu HF, et al. Molecular analysis of HLA-DRB1 allelic associations with systemic lupus erythematous and lupus nephritis in Taiwan. Lupus. 2009;18(8):698-704.

32. Yang $\mathrm{R}$, Cui Z, Zhao J, Zhao MH. The role of HLA-DRB1 alleles on susceptibility of Chinese patients with anti-GBM disease. Clin Immunol. 2009;133(2):245-50.

33. Chang DY, Luo H, Zhou XJ, Chen M, Zhao MH. Association of HLA genes with clinical outcomes of ANCA-associated vasculitis. CJASN. 2012;7(8):1293-9.

34. Perez-Luque E, Malacara JM, Olivo-Diaz A, Alaez C, Debaz H, Vazquez-Garcia M, et al. Contribution of HLA class II genes to end stage renal disease in mexican patients with type 2 diabetes mellitus. Hum Immunol. 2000;61(10):1031-8.

35. El-Gezawy EM, Baset HA, Nasif KA, Osama A, AbdelAzeem HG, Ali M, et al. Human leukocyte antigens as a risk factor for the primary diseases leading to end stage renal disease in Egyptian patients. Egypt J Immunol/ Egyptian Asso Immunologists. 2011;18(2):13-21.

36. Doxiadis II, De Lange P, De Vries E, Persijn GG, Claas FH. Protective and susceptible HLA polymorphisms in IgA nephropathy patients with endstage renal failure. Tissue Antigens. 2001;57(4):344-7.

37. Tighe MR, Hall MA, Barbado M, Cardi E, Welsh Kl, Ciclitira PJ. HLA class II alleles associated with celiac disease susceptibility in a southern European population. Tissue Antigens. 1992;40(2):90-7.

38. Chou HT, Chen $\mathrm{CH}$, Chen JY, Chang KC. Association of HLA DRB1-DQA1DQB1 haplotypes with rheumatic heart disease in Taiwan. Int J Cardiol. 2008;128(3):434-5.

39. Madeleine MM, Brumback B, Cushing-Haugen KL, Schwartz SM, Daling JR, Smith AG, et al. Human leukocyte antigen class II and cervical cancer risk: a population-based study. J Infect Dis. 2002;186(11):1565-74.

40. Yang J, Qiao HL, Zhang YW, Jia L, Tian X, Gao N. HLA-DRB genotype and specific IgE responses in patients with allergies to penicillins. Chin Med J. 2006;119(6):458-66.

41. Hiki Y, Kobayashi Y, Tateno S, Sada M, Kashiwagi N. Strong association of HLA-DR4 with benign IgA nephropathy. Nephron. 1982;32(3):222-6.

42. Mosaad YM, Mansour M, Al-Muzairai I, Al-Otabi T, Abdul-Moneam M, Al-Attiyah $\mathrm{R}$, et al. Association between Human Leukocyte Antigens (HLA-A, $-B$, and -DR) and end-stage renal disease in Kuwaiti patients awaiting transplantation. Ren Fail. 2014;36(8):1317-21.

43. Almogren A, Shakoor Z, Hamam KD. Human leucocyte antigens: their association with end-stage renal disease in Saudi patients awaiting transplantation. Br J Biomed Sci. 2012;69(4):159-63.

44. Freedman BI, Spray BJ, Heise ER. HLA associations in IgA nephropathy and focal and segmental glomerulosclerosis. Am J Kidney Dis : Off J National Kidney Foundation. 1994;23(3):352-7.

45. Alamartine E, Sabatier JC, Guerin C, Berliet JM, Berthoux F. Prognostic factors in mesangial lgA glomerulonephritis: an extensive study with univariate and multivariate analyses. Am J Kidney Dis: Off J National Kidney Foundation. 1991;18(1):12-9.

46. Berthoux FC, Genin C, Gagne A, Le Petit JC, Sabatier JC. HLA Bw35 antigen and mesangial IgA glomerulo-nephritis: a poor prognosis marker? Proc Euro Dialysis Transplant Assoc European Dialysis Transplant Assoc. 1979;16:551-5.

47. Cao HX, Li M, Nie J, Wang W, Zhou SF, Yu XQ. Human leukocyte antigen DRB1 alleles predict risk and disease progression of immunoglobulin A nephropathy in Han Chinese. Am J Nephrol. 2008;28(4):684-91.
48. Raguenes O, Mercier B, Cledes J, Whebe B, Ferec C. HLA class II typing and idiopathic IgA nephropathy (IgAN): DQB1*0301, a possible marker of unfavorable outcome. Tissue Antigens. 1995;45(4):246-9.

49. Hiki Y, Kobayashi Y, Ookubo M, Obata F, Kashiwagi N. Association of HLADQw4 with IgA nephropathy in the Japanese population. Nephron. 1991;58(1):109-11.

50. Chevrier D, Giral M, Perrichot R, Latinne D, Coville P, Muller JY, et al. Idiopathic and secondary membranous nephropathy and polymorphism at TAP1 and HLA-DMA loci. Tissue Antigens. 1997;50(2):164-9.

51. Huang CC. Strong association of HLA-DR3 in Chinese patients with idiopathic membranous nephropathy. Tissue Antigens. 1989;33(3):425-6.

52. Freedman BI, Spray BJ, Dunston GM, Heise ER. HLA associations in end-stage renal disease due to membranous glomerulonephritis: HLA-DR3 associations with progressive renal injury. Southeastern Organ Procurement Foundation. Am J Kidney Dis : Off J National Kidney Foundation. 1994;23(6):797-802.

53. Reichert $L$, Koene RA, Wetzels JF. Prognostic factors in idiopathic membranous nephropathy. Am J Kidney Dis: Off J National Kidney Foundation. 1998;31(1):1-11.

54. Bhimma R, Hammond MG, Coovadia HM, Adhikari M, Connolly CA. HLA class I and II in black children with hepatitis B virus-associated membranous nephropathy. Kidney Int. 2002;61(4):1510-5.

55. Haskell LP, Glicklich D, Senitzer D. HLA associations in heroin-associated nephropathy. Am J Kidney Dis: Off J National Kidney Foundation. 1988;12(1):45-50.

56. Freedman BI, Espeland MA, Heise ER, Adams PL, Buckalew Jr VM, Canzanello VJ. Racial differences in HLA antigen frequency and hypertensive renal failure. Am J Hypertens. 1991:4(5 Pt 1):393-8.

\section{Submit your next manuscript to BioMed Central and take full advantage of:}

- Convenient online submission

- Thorough peer review

- No space constraints or color figure charges

- Immediate publication on acceptance

- Inclusion in PubMed, CAS, Scopus and Google Scholar

- Research which is freely available for redistribution 